\title{
The Influence of Competence, Motivation, and Organisational Culture to High School Teacher Job Satisfaction and Performance
}

\author{
H. Muhammad Arifin ${ }^{1}$ \\ ${ }^{1}$ School of Communication, Muhammadiyah Jayapura Abepantai street Kota Jayapura, Papua, Indonesia \\ Correspondence: H. Muhammad Arifin, School of Communication, Muhammadiyah Jayapura Abepantai street \\ Jayapura city, Papua, Indonesia. E-mail: arifinmuhammad623@yahoo.com
}

Received: August 11, 2014 Accepted: September 29, 2014 Online Published: December 30, 2014

doi:10.5539/ies.v8n1p38

URL: http://dx.doi.org/10.5539/ies.v8n1p38

\begin{abstract}
The study aims to find out and analyze the influence of competence, motivation, and organizational competence to high school teacher job satisfaction and performance in Jayapura City, Papua, Indonesia. The study was conducted on 117 respondents of 346 teachers by means of questionnaire. Data is analyzed by SEM analysis method in AMOS program. Findings indicate that competence and organizational culture affect positively and insignificantly teacher job satisfaction. While, job motivation affects positively and significantly teacher job satisfaction, but it did not give any significant effect on teacher performance. Competence and job satisfaction affect positively and significantly teacher performance, in fact organizational culture just has positive but insignificant effect to job satisfaction.
\end{abstract}

Keywords: competence, motivation, organisational culture, teacher, job satisfaction, job performance

\section{Introduction}

Among human resource quality competitions in ASEAN countries, Indonesia is left behind at the low rank. Some causal factors are follows: (a) high school output has not been ready to join vocation, (b) Indonesia's human development index (HDI) by 2005 is at 110 from 170 countries (Madaria, 2013), (c) Indonesia's academic quality for natural science, math, and competence based on the findings of Program for International Student Assessment (PISA) in 2003 found that Indonesia ranks at 38 from 41 countries in natural science and 39 for math proficiency, and (d) natural science and technology proficiency are left behind, even it ranks in the seventh nation among ASEAN countries (Madaria, 2013).

Phenomena above indicates that the implementation of education administration system in Jayapura City has not been effective, especially for curriculum, human resource quality, budget, institutional, and coordination as outlined in Laws Number 20 of 2003 on National Education System. Among those administration systems, human resource quality, especially for educators have not met the standard to support education quality (Hasbullah, 2006). It can be pointed out by gap theory of Dessler (2007) where the success of human resource in improving performance is affected by competence, motivation, and discipline supporting means. Furthermore, Hasbullah (2006) states that the success of educator in improving national education system cannot be split up by the importance of competence, motivation, and discipline supporting means in affecting teacher performance. Further gap research is proposed by William (2005) entitled The Competence, Motivation and Facilities Affect toward Performance and Increasing The Quality of Education in Australia College and Miako (2008) who focuses on performance strengthening through facility improvement, motivation, culture, and job competence toward the improvement of human resource quality. The difference between this study and the previous ones is discipline by means and culture, while the similarity lies on the competence and motivation which gives specific characteristics herein.

Moreover, comprehension on teacher competence refers to the Regulations of Ministry of National Education of the Republic of Indonesia Number 16 of 2007 concerning Teacher Academic Qualification and Competence. It is outlined that Teacher Competence Standard is developed completely from 4 main competences as follows: (1) pedagogical competence, (2) personality, (3) social, and (4) professionalism. These four competences are integrated into teacher performance (Maklassa, 2012).

Sahlan (2002) divides work motivation possessed by every human into three large groups based on the needs, 
awareness, and support grant (reinforcement). Under category of needs, some theories are proposed by Maslow (Maslow's need hierarchy theory), ERG Alderfer (Alderfer's ERG theory), and Herzberg (Herzberg's motivator-hygiene theory) by setting indicator that admission on success and responsibility is greater than autonomy and career opportunity (Sahlan, 2002). Motivation theory by Herzberg (Robbins, 2006) states that intrinsic motivation such as admission on success and responsibility is greater than autonomy and self-development opportunity.

Robbins (2006) states that culture is a set of values which are learned, convinced and having standard of knowledge, morality, laws, and attitude as conveyed by individual, organization, or community to behave in compliance with how basic habit regard him. According to Schein (1992), the existence of culture in organization has three levels, i.e. artifacts, espoused value, and underlying assumptions. Then, Luthans (1998) states that culture is norms and values which direct behavior of organization member. While, Kreitner and Kinicki (2000) propose organizational culture as harmony of individual values and organizational values which significantly affect job satisfaction and employee performance. Research by Kotter and Heskett (1992) found that organizational culture may upgrade long-term organizational performance.

Human will satisfy if they found no differences between his expectation and reality since his minimum limit had been reached. Job satisfaction may be comprehended by three aspects (Luthans, 2002); (a) Job satisfaction, a kind of employee responds to the condition of working environment. (b) Job satisfaction is often assessed based on work output or performance. (c) Job satisfaction relates to other attitudes performed by every employee. Further, there are 6 factors affecting job satisfaction, i.e. the work itself, wage/salary, promotion, supervision, work group, and connection/work environment. Handoko (2003) states that job satisfaction is happy or unhappy emotional condition. Other theories on job satisfaction are proposed by Mathis and Jackson (2000), Robbins (2006), and Sigit (2003) that it may create positive and negative response to what have been got by mankind, so it also may strengthen and weaken employee performance.

According to Wibowo (2009) The performance comes from the meaning of performance. Others also gives an understanding of performance as performance, work output, or achievement. Indeed, performance has a broader meaning, it does not only cover the work output, but also on how the work are processed. Furthermore, Mangkuprawira describes performance by mathematic equation as an interactional function between ability (A), motivation $(\mathrm{M})$ and opportunity $(\mathrm{O})$, hence performance $=f(\mathrm{~A} \times \mathrm{M} \times \mathrm{O})$. It means that performance is the function of ability, motivation, and opportunity (Robbins: 2006). Thereby, performance is determined by factors of ability, motivation, and opportunity. Prawirosentono (1999) suggests that the word of performance may be attained by personal or a group of people in an organization in compliance with each party's authority and responsibility to reach the intended organization goals by legal manner without breaking the rules as well as obeying the moral and ethics. In the other level, Mangkunegara (2005) proposes that teacher performance is the work output either its quality or quantity attained by human resource based on the consideration of work efficiency and effectiveness in performing the duties along with the responsibilities charged on him. Assessment of teacher performance refers to work quality, working rapidity/accuracy, work initiative, work ability, and communication. Other explanation of performance is proposed by Rivai (2005) that performance is concrete work output which can be observed and measured based on its quantity, quality, effectiveness, and efficiency. As explained above, research hypothesis may be formulated that competence, motivation, organizational culture affect high school teachers job satisfaction in Jayapura City, while competence, motivation, organizational culture, and job satisfaction affect high school teacher performance in Jayapura City.

\section{Methodology}

The study is designed to answer the formulated problems through hypothesis testing. This design made by Kerlinger (2000) is an inquiry structure which is arranged in such way to help researcher acquire the exact answers. It applies deductive approach consisting of exploratory research to seek some relationships which are relatively new and explanatory research, a research which is conducted by explaining indications emerged from research objects. By applying deductive approach, the researcher strives to see the data empirically and systematically, then compare them with the existing theories. As viewed from the goals, causal study tries to explain causal relationship on the influence of competence, motivation, and organizational culture to high school teacher satisfaction and performance in Jayapura City.

\subsection{Conceptual Framework}

The study is conducted in high school in Jayapura City. Taken population and respondents are teachers teaching in the schools with last grade students. Taken teacher sample is 117 of 346 people randomly selected. The amount is based on the equation of Slovin where $\mathrm{n}=\mathrm{N} /(\mathrm{N} . \mathrm{d} 2+1)$, then: $346 /(346(0.075) 2+1)=117$ respondent. 


\subsection{Variable Classification}

The study is classified into three variable groups; first, competence, motivation, and organizational culture belongs to independent variables (exogenous variables); second, teacher job satisfaction belongs to intervening variables and third, teacher performance belongs to endogenous variable. Collected data from questionnaire is calculated by applying Likert scale; 5 for the highest value and 1 for the lowest (Sugiyono, 2003). Point 5 indicates very good, 4 for good, 3 for average, 2 for fair, and 1 for poor.

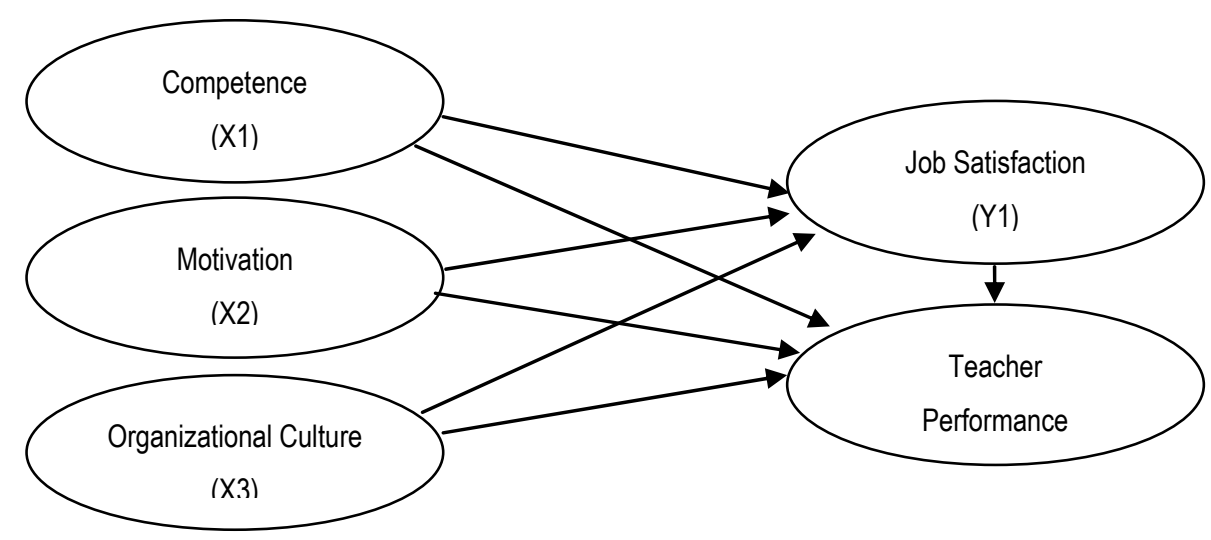

Figure 1. Flow chart on research conceptual framework

\section{Statistical Test}

\subsection{Analysis Model}

Essentially, the study is going to obtain the best model in explaining the influence of competence, motivation, and organizational culture to teacher satisfaction and performance in Jayapura City.

Then, the study applies statistical technique called Structural Equation Model (SEM). According to Ferdinand (2002), SEM is well matched to: (1) confirm undimensionality of various indicators for a dimension/construction, (2) examine compatibility/accuracy of a model based on the observed empirical data, (3) examine model compatibility as well as causality relation of inter-observed/built factors in the model. This study referred to the second concept. Basically, a complete modeling consists of measurement model and structural model. Aim of the measurement model is to confirm a dimension or a factor based on its empirical indicator, while structural model is a model concerning structure of relationship which shape or explain causality of inter-factor. Then, in order to build up a complete modeling, there should be an equation model as follows:

$$
\begin{array}{ll}
\mathrm{Y} 1=\mathrm{f}(\mathrm{X} 1+\mathrm{X} 2+\mathrm{X} 3) \text { and } & \mathrm{Y} 2=\mathrm{f}(\mathrm{X} 1, \mathrm{X} 2, \mathrm{X} 3, \mathrm{Y} 1) \\
\mathrm{Y} 1=\text { Job satisfaction } & \mathrm{Y} 2=\text { Teacher performance } \\
\mathrm{X} 1=\text { Competence } & \mathrm{X} 1=\text { Competence } \\
\mathrm{X} 2=\text { Motivation } & \mathrm{X} 2=\text { Motivation } \\
\mathrm{X} 2=\text { Motivation } & \mathrm{X} 3=\text { Organizational Culture } \\
\mathrm{X} 3=\text { Organizational Culture } & \mathrm{Y} 1=\text { Job Satisfaction }
\end{array}
$$




\subsection{Testing on Good of Fit Index and Evaluation Model}

Table 1. Good of fit index table for evaluation model

\begin{tabular}{|c|c|c|}
\hline \multicolumn{2}{|l|}{ Goodness } & \multirow{2}{*}{$\begin{array}{l}\text { Cut-Of } \\
\text { Value }\end{array}$} \\
\hline $\begin{array}{ll}\text { Of } & \text { Fit } \\
\text { Index } & \end{array}$ & Information & \\
\hline Chi-square & $\begin{array}{l}\text { To test if estimated population covariance }=\text { sample covariance (if the model } \\
\text { matches the data) Very sensitive to huge sample (above 200). }\end{array}$ & $\begin{array}{l}\text { Small amount is } \\
\text { prioritized }\end{array}$ \\
\hline Probability & $\begin{array}{l}\text { Significance test toward the difference of covariance matrix and estimated } \\
\text { matrix. }\end{array}$ & $\leq 0.05$ \\
\hline RMSEA & Compensate the weakness of Chi-Square to large sample & $\leq 0.08$ \\
\hline GFI & $\begin{array}{l}\text { Calculate weighted proportion of variance in sample matrix as explained by } \\
\text { covariance matrix of estimated population (analog by R2 in multiple } \\
\text { regression) }\end{array}$ & $\geq 0.90$ \\
\hline AGFI & GFI as matched to DF & $\geq 0.90$ \\
\hline CMIND/DF & Compatibility of data and model & $\leq 2.00$ \\
\hline TLI & Comparison between the examined model and baseline model & $\geq 0.95$ \\
\hline CFI & $\begin{array}{l}\text { Feasibility test for the model which is not sensitive to sample largeness and } \\
\text { model complexity }\end{array}$ & $\geq 0.94$ \\
\hline
\end{tabular}

Source: Agusty (2002).

\subsection{Hypothesis Testing Result}

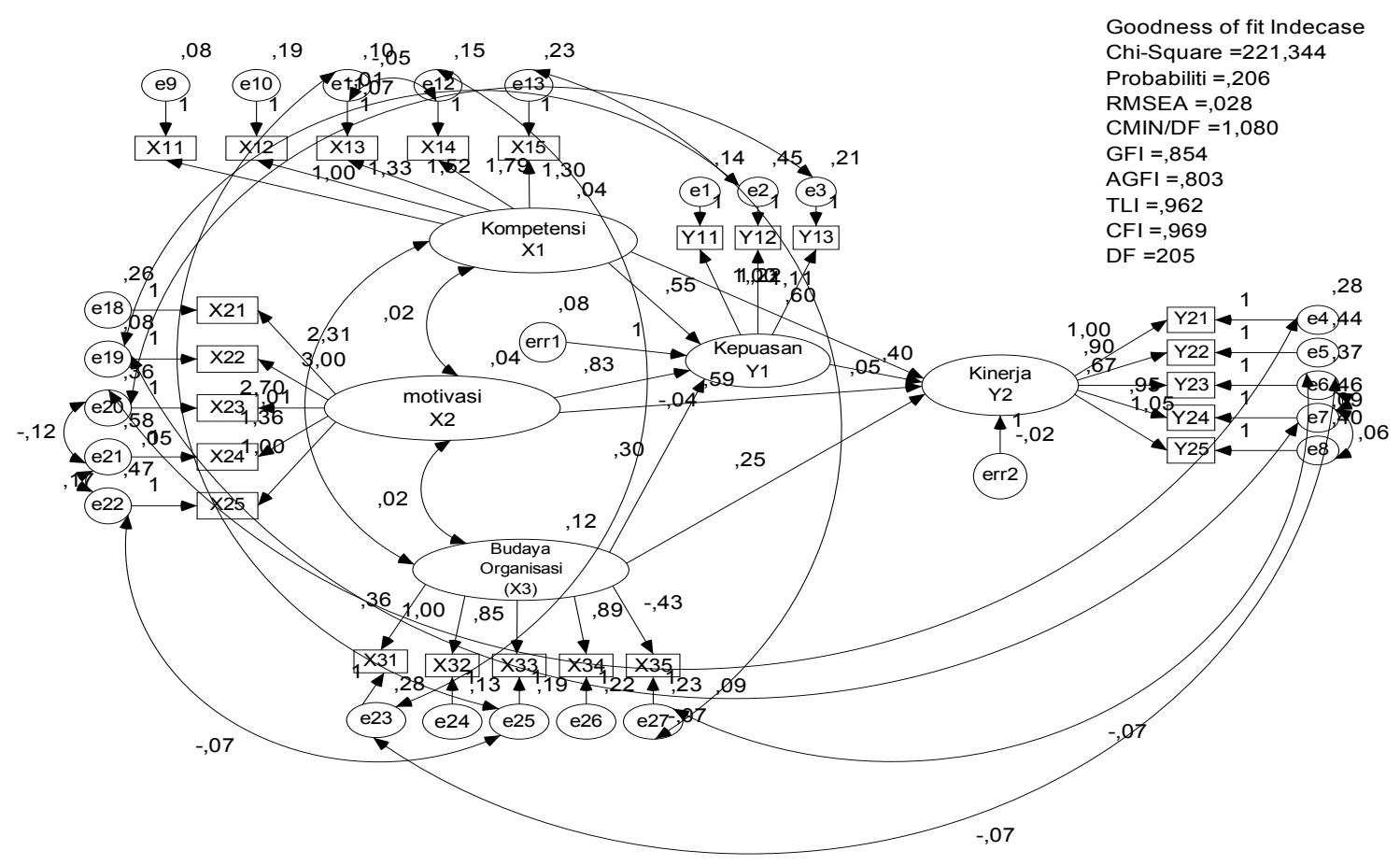

Figure 2. Hypothesis testing result 
Based on the fitting SEM model, there conducts significance test of inter-variable relationship. It is conducted partially by comparing value of critical ratio (CR) or probability (p) to regression weights value. Critical ratio (CR) value equals to critical student (t-value) value in ordinary regression model (non-structural). This complete model may explain causal relationship which is interlaced among variables of competence, motivation, and organizational culture toward teacher job satisfaction and performance reached by the development of single model of every previous tested factor. After executing model testing, the following are obtained good of fit index values which depict high Chi-Square value by 221,344 with probability 0.206 and CMIN/DF 1.080 , GFI by 0.854 and AGFI 0.803 , TLI by 0.962 , CFI by 0.969 , and RMSEA by 0.028 . Calculation under criteria of goodness of fit on the model as described above depicts a well-built compatibility. Therefore, conclusion may be made that the model delineates causal relationship of every and inter-observed variables which may be accepted and used to the upcoming needs.

\subsection{Hypothesis Testing}

Hypothesis testing in this research model applies t-test and critical ratio $\left(\mathrm{t}_{\mathrm{count}}\right)$ comparison by significance level of alpha $5 \%$. Null hypothesis is accepted if probability (p) value $>0.05$; it means the influence of inter-construct lane is insignificant. Alternative hypothesis is accepted if $p<0.05$. Influence of inter-construct in the study consists of direct effect and indirect effect. Analysis on inter-construct direct effect, indirect effect, and total effect of the model may be compared to evaluate the influence of each construct to direct effect, i.e. coefficient of all coefficient line by one-tailed arrow. While, indirect effect through an intervening variable and total effect are the influence of various relationship (Ferdinand, 2002). In this study, direct effect of the model was analyzed as the purpose of this study namely to determine and analyze the influence of competence, motivation, and organizational competence to high school teacher job satisfaction and performance in Jayapura City, Papua, Indonesia.

If direct influence value of a lane equals to its total influence, it found no intervening variable therein. Test result on direct effects, indirect effects, and total effects are shown in the following table as hypothesis testing result by comparing t-count value or critical ration and t-table value. If t-count value is larger than $t$-table, relationship of significance variable and? This research model makes degree of freedom $=3$ (final model), t-table value $(\alpha=$ $0.05)$ by 1.96

Table 2. Hypothesis testing result table of direct effect

\begin{tabular}{clccccc}
\hline \multirow{2}{*}{ Hip } & \multirow{2}{*}{ Independent Variable } & \multirow{2}{*}{ Dependent Variable } & \multicolumn{4}{c}{ Direct Effect } \\
\cline { 4 - 6 } & & Standardize & CR & P-value & Information \\
\hline 1 & Competence & Job Satisfaction & 0.552 & 1.945 & 0.052 & Insignificant \\
2 & Work motivation & Job Satisfaction & 0.834 & 1.978 & 0.048 & Significant \\
3 & Organizational culture & Job Satisfaction & 0.297 & 1.928 & 0.054 & Insignificant \\
4 & Competence & Performance & 0.603 & 2.317 & 0.021 & Significant \\
5 & Work Motivation & Performance & 0.598 & 1.667 & 0.095 & Insignificant \\
6 & Organizational Culture & Performance & 0.252 & 1.824 & 0.068 & Insignificant \\
7 & Job Satisfaction & Performance & 0.398 & 2.214 & 0.027 & Significant \\
\hline
\end{tabular}

Source: Data Processing Result, 2014.

\section{Discussion on the Findings}

Finding of the study conforms to the found fact and reality on the influence of competence, motivation, and organizational competence to high school teacher job satisfaction and performance in Jayapura City, Papua. Hypothesis testing result as seen in table above is outlined below:

\subsection{The Influence of Competence to Job Satisfaction}

The findings explain that the influence of competence affect positively to teacher job satisfaction, but insignificantly. The findings do not in line with Fletcher (in Madaria, 2013) where human development is form of assessment on essential potency of personal competence in actualizing job satisfaction. Similar findings of Devi (2007), Labbai (2008), Waluyo (2013), and Haskas also assert that human resource development through 
competence improvement has positive and significant effect to job satisfaction. This study indicated that although competence gave a positive effect on job satisfaction, but it is no any significance effect.

\subsection{The Influence of Motivation to Job Satisfaction}

The finding proves that work motivation affects positively and significantly teacher job satisfaction. Previously reported that the form of motivation affecting satisfaction are motivation on the admission of achievement, opportunity to reach an achievement, career, responsibility grant, and opportunity to progress more. This kind of motivation may become consideration to realize teacher job satisfaction. It is encouraged by theory of Herzberg (Sahlan, 2002), Brahmasari and Suprayetno (2008) with their similar finding asserting that work motivation affects job satisfaction. Other finding by Al Khalifah (2002) equals to this study that work motivation affects job satisfaction and so does Haskas (2013) who proposes similar finding that work motivation affects lecturer job satisfaction. This study further supports that job motivation gives a big contribution on job satisfaction.

\subsection{The Influence of Organizational Culture to Job Satisfaction}

The finding shows that organizational culture affects positively and insignificantly job satisfaction. It means that implementation of honesty, integrity, identity, and working disciplinary have not been able to increase teacher job satisfaction. Agree with the finding of Madaria (2013), organizational culture affects positively and insignificantly job satisfaction. However, it disagrees with theory of organizational culture prospective proposed by Gullman (as referred in Madaria, 2013) that organizational culture prospective is a realization of job satisfaction. This study indicates that organizational culture is not the main factor on the successing of job satisfaction, but it is a supporting factor. Firdaus (2008) and Brahmasari and Suprayetno (2008) also state that organization affects job satisfaction.

\subsection{The Influence of Competence to Performance}

The finding proves that competence has positive and significant effect on teacher performance. It means that the higher competence may increase teacher performance. The finding agrees with reputation theory of Borgutee (in Madaria, 2013) that reputation (performance) is determined by human resource development through competence. Confirming the study of Madaria (2013), human resource development by means of competence improvement affects positively and significantly employee performance. So does the study of Waluyo (2013) that teacher competence through pedagogy, personality, social, and professionalism affects significantly teacher performance.

\subsection{The Influence of Motivation to Performance}

The finding portrays that motivation affects positively and insignificantly teacher performance. It proves that school authority rarely admits job achievement and gives opportunity to develop themselves, restricts a greater responsibility and teacher creativity. However, this finding disagrees with behavioral reinforcement as proposed by Haderston (in Madaria, 2013) asserting that everyone will be motivated in compliance with his roles of behavioral factor to change and to realize the performance. So does the study of Al Khalifah (2002) stating that work motivation affect performance.

\subsection{The Influence of Organizational Culture to Performance}

Implementation of organizational culture in the study depicts the existence of positive effect and insignificant effect on teacher performance. It means that the role of organizational culture is so important in determining teacher success to increase his performance, but in fact it does not run well. Then, organizational culture in form of honesty, integrity, identity, discipline, and output-orientation which have been applied up to now have not run optimal to be a binding tool to reach the school goals. It is different from the finding of Firdaus (2008) proposing that organizational culture affects the performance, so do the finding of Brahmasari and Suprayetno (2008).

\subsection{The Influence of Job Satisfaction to Employee Performance}

It is proved that job satisfaction affects positively and significantly the performance, meaning that the higher teacher job satisfaction, the higher teacher performance. It conforms job inspiration theory proposed by Walgert (Madaria, 2013) that job satisfaction may increase performance attainment. And so Hersey's equity theory in Robbins (2006), goal theory, and the finding of Devi who have same notion in analyzing job satisfaction which affects performance positively and significantly.

\section{Conclusion}

Competence affected positively and insignificantly teacher job satisfaction since pedagogical competence, social, personality, and professional had not been applied well. It was different to work motivation in which it affects positively and significantly teacher job satisfaction. Meawhile, organizational culture affects positively and 
insignificantly job satisfaction since the role of organizational culture cannot raise job satisfaction. Moreover, competence affects positively and significantly teacher performance due to competence improvement and upgrading of every teacher. In addition, motivation affects positively and insignificantly teacher performance whilst, organizational culture affects positively and insignificantly teacher performance since identity, integrity, low discipline, indeed, output-orientation do not encourage high working spirit. Lastly, satisfaction affects positively and significantly teacher performance. If job satisfaction may be upgraded, it will encourage teacher to improve their performance.

\section{Suggestion}

Based on the findings above, it can be suggested that encouraging of teachers work motivation can be done through marking up admission, granting a greater responsibility, encouraging teachers creativity, and giving opportunity to expand teacher career. Besides that, setting up the culture to be school competitiveness by maintaining honesty, integrity, identity, and discipline which may create teachers job satisfaction. Besides, school has to be able to maintain and reform competence, motivation, organizational culture, and job satisfaction, thus it may set up high school teacher performance improvement in Jayapura City, Papua.

\section{References}

Agusty, F. (2002). Struktural Equation Modeling Dalam Penelitian Manajemen. FE Undip, Semarang, Indonesia.

Al Khalifa, \& Ali, K. (2002). On The Relationship between Initial Motivation, Satisfaction and Performance in Joint Ventures. University of Bahrain Amstrong.

Depdiknas. (2003). Standar Kompetensi Guru SLTA. Jakarta, Indonesia.

Dessler. (2007). Human Resources Managemen (9th ed.). Upper Saddle River, Prentice Hall, New Jersey.

Devi, M. (2007). Pengaruh Pengembangan SDM, Motivasi dan Budaya Organisasi terhadap Kepuasan dan Kinerja Karyawan PT. Indofood Fritolay Jakarta, Indonesia.

Firdaus. (2008). Pengaruh Budaya Organisasi, Kompensasi dan Kecerdasan Emosional terhadap kinerja karyawan.

Handoko, H. T. (2003). Manajemen Personalia dan Sumber Daya Manusia. Edisi Kedua, BPFE, Yogyakarta. Company, California USA.

Hasbullah. (2006). Manajemen Pendidikan. Penerbit Bina Rupa, Jakarta, Indonesia.

Haskas, Y. (2013). Pengaruh Kompetensi Terhadap Motivasi, Prestasi, Penghargaan dan Kepuasan Kerja Dosen pada Sekolah Tinggi Ilmu Kesehatan Provinsi Sulawesi Selatan. Disertasi, Unpublished PPs-UMI Makassar, Indonesia.

Kerlingger, L. (2000). Human Resources Management. Published by Library State, California.

Kotter, J. P., \& James, L. H. (1992). Corporate Culture and Performance. The Free Press, New York.

Kreitner, R., \& Kinicki, A. (2000). Organization Behavior. Boston Richard D. Irwin, Inc.

Labbai, S. (2008). Pengaruh komitmen kerja, Pengembangan, Budaya organisasi, dan motivasi terhadap Peningkatan Prestasi, Kepuasan dan kinerja karyawan PT. Mega sari Perdana, Surabaya, Indonesia.

Luthans, F. (1998). Organizational Behavior (4th ed.). McGraw-Hill Book, International Student Edition, Singapore.

Luthans, F. (2002). Organizational Behavior (6th ed.). Singapore: McGraw-Hill International Editions.

Madaria, K. (2013). Pengaruh Pengembangan SDM, Budaya Organisasi, Motivasi Terhadap Kepuasan Kerja dan Kinerja Karyawan PT.Aneka Tambang Sulawesi Tenggara. Disertasi, Unpubished, PPs-UMI Makassar, Indonesia.

Maklassa. (2012). Pengaruh Kompetensi, Motivasi, Sarana dan Prasarana Terhadap Kinerja Guru dan Kualitas Pendidikan di Provinsi Sulawesi Selatan. Disertasi PPs-UMI. Unpublisher, Makassar, Indonesia.

Mangkunegara, A. P. (2005). Evaluasi Kinerja SDM. PT Refika Aditama Bandung, Indonesia.

Mangkuprawira, S. (2007). Manajemen Sumber Daya Manusia Strategik. Ghalia, Jakarta, Indonesia.

Mathis, \& Jackson. (2000). Organization Commitment. Public Performance \& Managerial Review.

Miako, S. (2008). The Strength of Performance through Improvement Work Facility, Motivation, Culture and Work Ability toward Increasing the Quality of Human Resource in Toyota Inc. Japan. Journal of HRM. 
http://dx.doi.org/10.5105/jse.28.295

Natsir, M. (2011). Pengaruh Gaya Kepemimpinan, Budaya Organiisasi, dan Kompetensi Terhadap Motivasi dan Kinerja Guru SMA Kota Makassar. Disertasi, Unpublished, PPs-UMI Makassar.

Permendiknas No. 16, 17, and 18. (2007). Standar Kualifikasi Guru dan Sertifikasi Guru dalam Jabatan. Jakarta: CV Mini Abadi.

Prawirosentono, S. (2001). Kebijakan Prestasi kerja Karyawan. BPFE, Yogyakarta, Indonesia.

Rivai,V. (2005). Manajemen Sumber Daya Manusia. Raja Grafindo Persada, Jakarta, Indonesia.

Robbins, P. S. (2006). Organization Behavior (10th ed.). Benyamin Molan (Alih Bahasa ) Perilaku Organisasi, Edisi lengkap. Gramedia. Jakarta, Indonesia.

Sahlan, A. (2002). Teori Motivasi. Dalam Pendekatan Psikologi Industri dan Organisasi, Studia Press, Jakarta, Indonesia.

Schein, E. H. (1992). Organizational Culture and Leadership. San Francisco: Bass Publishers.

Sigit, S. (2003). Perilaku Organisasional. Penerbitan FE, UGM, Yogyakarta.

Sugiyono. (2003). Metode Penelitian Administrasi. Alfabeta, Bandung, Indonesia.

UU No 20 tahun. (2003). Sistem Pendidikan Nasional. Citra Umbara:Bandung, Indonesia.

Waluyo, H. S. (2013). Pengaruh Kompetensi Kpribadiaan dan Sosial Terhadap Kompetensi Pedagogik dan Profesional serta Dampaknya pada Kinerja Guru SMA di Kota Makassar. Disertasi,Unpublished, PPs-UMI Makassar, Indonesia.

Wibowo. (2008). Manajemen Kinerja. Jakarta. Penerbit: Raja grafindo Persada, Indonesia.

William, S. (2005). The Competence, Motivation and Facilities Affect toward Performance and Increasing The Quality of Education in Australia College. Journal Human Resource Management.

\section{Copyrights}

Copyright for this article is retained by the author(s), with first publication rights granted to the journal.

This is an open-access article distributed under the terms and conditions of the Creative Commons Attribution license (http://creativecommons.org/licenses/by/3.0/). 